\title{
17. The Election in Chuave Open Electorate
}

\author{
William Steven Gari Kaupa
}

The 2007 election for Chuave Open in Simbu Province, which closely followed by-elections in Chuave Open in August 2006 and Simbu Provincial in 2004, was quieter than previous general elections. In 2002 (and 1997) many candidates had been prevented from travelling widely to campaign, and there was a great deal of intimidation of voters and 'forcing' of the vote.

The Chuave people have a high level of tribal contestation and also ample experience of preferential voting, so they knew how to exploit limited preferential voting (LPV) to their advantage. However, initial good impressions need to be re-examined in evaluating this election. Most candidates promoted good governance messages and discouraged corrupt practices in their opening campaign speeches, but the same candidates engaged in unscrupulous campaign gifting, exploiting customary practices and thereby displaying double standards. The administration of the election and the security environment were good, but in many places the polling could not be properly administered because polling officials and security personnel were powerless against community pressure.

The member of parliament (MP) elected under the LPV system gained a greatly increased mandate compared with previous MPs. Yet observers' findings reflect the underlying influence of Melanesian culture and the power of community consensus in influencing voting in the election. Voting was not free and fair; this had not changed much from 2002. In each polling place the LPV outcome was essentially the same as under the first-past-the-post (FPTP) system, in that community consensus overrode the secrecy of the ballot. A second major finding is that there was little impact from the Organic Law on the Integrity of Political Parties and Candidates, which was designed to strengthen political parties, create legislative stability, and promote national interests rather than parochialism. People voted in the hope of gaining community projects and meeting their local aspirations, rather than for the policies and candidates of political parties.

This chapter draws on the journals used by seven domestic observers at six polling places. Team members were asked to fill in 18 sections of the journal, covering topics from election administration, through candidates' tactics in campaigning and public reactions, to security responses, within a structured questionnaire. ${ }^{1}$

1 The questionnaire was prepared by Dr Nicole Haley from The Australian National University and Dr Ray Anere from the National Research Institute. The seven domestic observers were Margaret Melton from 


\section{The electorate}

Chuave Open electorate is in the east of Simbu Province bordering the Eastern Highlands. Within Simbu it abuts Karimui-Nomane Open electorate to the south and Sinasina-Yonggamugl to the west (Figure 17.1). The principal cash crop is smallholder coffee. A total of 30,876 eligible voters were registered for the poll. The Chuave electorate has three local-level governments (LLGs): Chuave, Elimbari and Siane. Chuave LLG has 13 wards with 10,077 registered voters, Elimbari has 16 wards with 10,794 registered voters, and Siane has 27 wards with 10,004 registered voters. Some 69 polling sites were gazetted across the total of 56 LLG wards for the 9 July poll. Multiple voting in Simbu Province by Eastern Highlanders, which caused the 2006 by-election, is still very much in evidence across Siane LLG area. Border crossing is also a problem in Chuave LLG, in the north at Mangiro and in the west at the border with SinasinaYonggamugl.

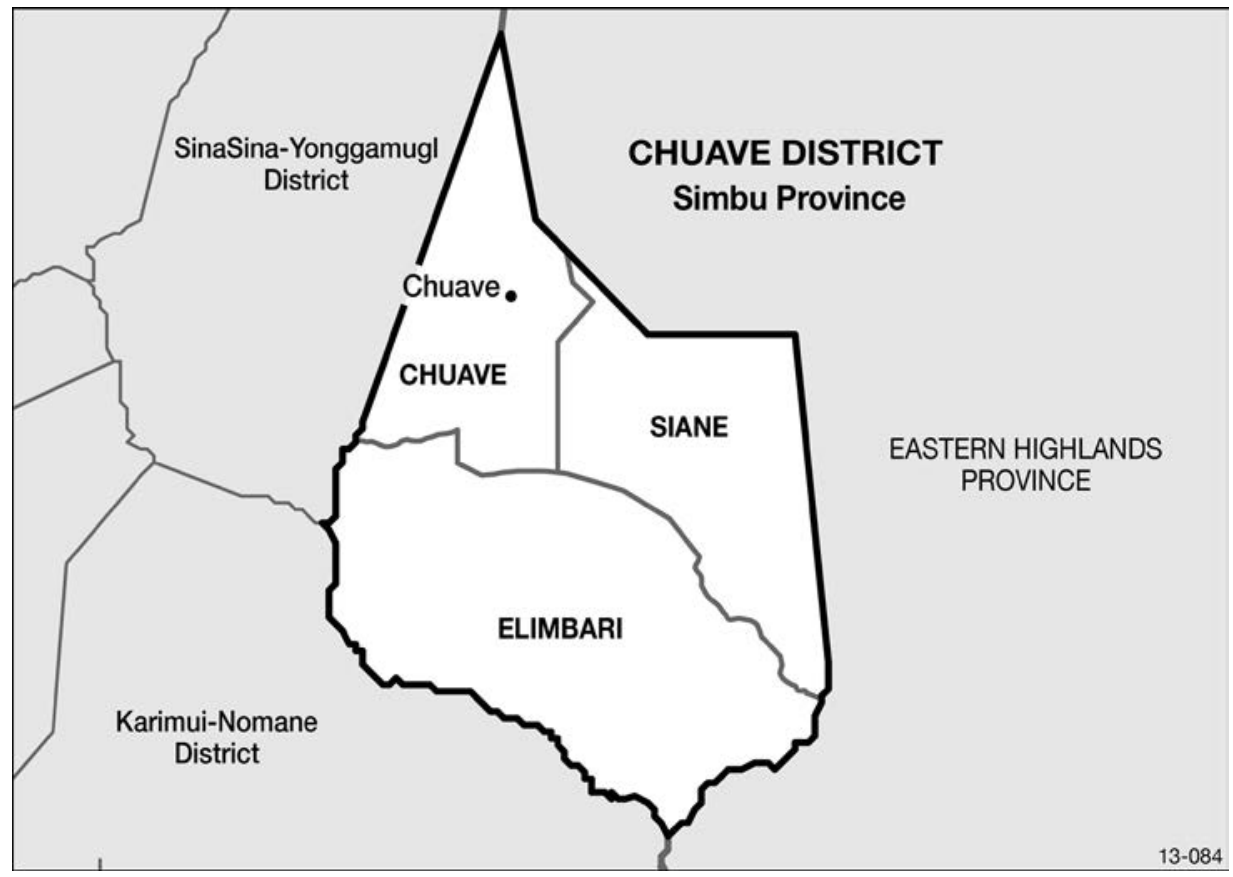

Figure 17.1: Chuave District

Chuave, Doreen Ale from Kundiawa, Boney Waine from Gumine, Eric Uba from Sinasina, Matthias Kin from Karimui-Nomane, Kamane Kiage from Chuave and Limbia Tiagoba from Tari Pori in the Southern Highlands. 


\section{Electoral awareness and civil society organization engagement}

Chuave people have good access to radio broadcasts and newspapers as the electorate is closer to Goroka and Kundiawa than other Simbu electorates. The findings from our questionnaire indicate that people had heard the radio advertisements from the Papua New Guinea Electoral Commission (PNGEC). They also mentioned that the LPV system was clearly explained by the Meri I Kirap Sapotim civil society organization and Simbu-based police during the awareness campaign.

\section{The voter survey}

140 voters (70 male and 70 female), most between the ages of 25 and 55, from around the Chuave electorate were interviewed on various aspects of the election. 40 percent said that they did not know that there was a new electoral roll. Fifteen percent indicated that they had filled out a claim-for-enrolment form while 40 percent stated that they thought they were enrolled. Forty-one percent of respondents said they had seen the verification teams in their areas, but only 14 percent reported that they had actually checked their names on the new roll.

Eighty-three percent of respondents stated that they were aware of the new LPV voting system and 54 percent said that they felt that they knew how to vote properly under LPV. Forty-three percent had attended LPV and civic awareness prior to the election, and of these 70 percent indicated that the LPV awareness would change the way they voted, especially in terms of the distribution of preferences. Sixty-eight percent had seen, read, or heard of, the PNGEC election advertisements on EMTV, radio, and in the newspapers. Seventy-one percent indicated they would be able to vote more freely than in the 2002 election. Twenty-three percent had heard about the new procedures for gender segregation at the time of polling. Seventy percent of respondents also said that they were now more aware of the dangers of unsafe sex and other consequences of being unfaithful in their marriages. Those interviewed spoke highly of Meri I Kirap Sapotim as an effective medium of communication and awareness, and praised the Simbu police for a job well done in ensuring security during the elections.

On the whole, the voter survey suggested that LPV and HIV/AIDS awareness were well conducted in the Chuave Open electorate, such that the majority of voters cast valid votes under the LPV system, and many understood the dangers of unsafe sex during the election. 
After the poll, 46 percent of people interviewed said that the awareness had changed the way they voted, but as revealed during the counting, local candidates still scored most votes. The awareness thus does not seem to have had much impact on voters' attitudes and behaviour (see below). Voter education and awareness has to be a long-term program and not one started just months before the issue of the writs. Part of the process must be that people become aware of the need to get on the electoral roll to participate in a free and fair electoral process.

\section{The new electoral roll}

A new roll was prepared for Chuave in late 2005; it was amended before the 2006 by-election and again before the 2007 general election. The 2002 common roll for Chuave Open carried 53,125 names, and 49,971 votes were used. The estimated adult population (projected from the 2000 census, which was itself inflated) was 23,156 , so that 215 percent of eligible citizens voted in 2002 . That would have included many under-age voters. In the May 2004 Simbu Provincial by-election the number of ballot papers distributed was arbitrarily reduced by 10 percent and some 44,375 votes were collected. In order to correct such anomalies, what was intended to be a completely new roll was constructed in October-November 2005, which reduced the roll size by 36 percent, leaving 34,115 names on the preliminary roll, 137 percent of the estimated adult population. In 2006, some 32,837 votes were collected (about 8000 more than the adult population). Only 1623 ballot papers (4.7 percent) were unused (Standish and Kaupa 2006:18-20). In practice, the so-called 'new electoral roll' had been based upon the previous common roll. In 2007 some 30,136 formal ballot papers were collected.

In contrast with the apparent success of the voter awareness program, there was little participation in voter registration. Only 15 percent of the 140 respondents to the questionnaire said they had completed their own enrolment claim forms, and only 14 percent had checked to verify their enrolment status. The rest of the people failed to understand the importance of electoral registration. The general assumption was that the kiap (government officials) and councillors would do the roll work for them.

The local observers reported that during the enrolment, forms had been filled in by ward councillors and kiap, not by the people. The kiap and councillors also did the verification of the new electoral roll. Most people said that the kiap and councillors who did the update did so according to their affiliations to candidates and their local interests. Most people never asked for an enrolment form or even gave their consent for the councillors or kiap to register their 
names on their behalf, and never bothered to verify their names on the new roll. The verification was done at Chuave District headquarters and the Kundiawa electoral office - both of which require quite an effort to get to.

The electoral roll was thus still problematic. However, the Chuave people, having experienced the 2006 by-election with the new alphabetical electoral roll, knew how they would vote, deviating from official procedures such as roll calls of listed names. People all over the electorate complained about the alphabetical layout of the roll, saying that in future the roll should be structured in accordance with how the community is organized through sub-clans and the lineage system. Unless that is done there is little chance of regulating voting and preventing fraud, because a poor roll leads to double voting, conflict over leftover papers, and other problems. The electoral roll updating should use the existing LLG ward structures. Screening committees are needed to enable the appointment of enrolment officials with integrity (weaknesses in the roll are further discussed below).

\section{Nomination and candidate information}

A total of 29 candidates nominated (compared with 24 in the 2006 by-election), of whom 13 were new candidates (Table 17.1). Chuave LLG and Elimbari LLG each had 10 candidates and Siane LLG had 9, so all LLGs' votes were fragmented. One candidate, Ananias Popo, died during the campaign period while in Wabag. Two former members of parliament, David Mai and David Anggo, contested along with the incumbent Jim Nomane. No women contested, although one had stood in 2002.

\section{Table 17.1: Candidate information, Chuave Open electorate}

\begin{tabular}{|c|c|c|c|c|c|}
\hline $\begin{array}{l}\text { Ballot } \\
\text { order }\end{array}$ & Candidate & $\begin{array}{l}\text { Previously } \\
\text { contested }\end{array}$ & LLG & $\begin{array}{l}\text { Education/ } \\
\text { occupation }\end{array}$ & Party \\
\hline 10 & George King Yauwe & & Siane & $\begin{array}{l}\text { UPNG; public } \\
\text { servant }\end{array}$ & $\begin{array}{l}\text { Peoples } \\
\text { Congress Party }\end{array}$ \\
\hline 11 & Supa Tony Tabie & 2006 & Elimbari & Educator & Independent \\
\hline 12 & Jack G. Kaupa & 2006 & Siane & & Independent \\
\hline 13 & Bomai Philip Tonari & & Elimbari & & Independent \\
\hline 14 & $\begin{array}{l}\text { Jim J. Nomane } \\
\text { Sitting MP }\end{array}$ & $\begin{array}{l}\text { Several } \\
\text { times }\end{array}$ & Siane & Unitech; Engineer & PNG Kantri Pati \\
\hline 15 & Peter lori Moorewer & 2006 & Elimbari & UPNG & Independent \\
\hline 16 & Alfred Rongo & $\begin{array}{l}\text { Several } \\
\text { times }\end{array}$ & Siane & UOG & National Party \\
\hline 17 & Abraham Gene Tisa & & Chuave & Unitech & Independent \\
\hline 18 & $\begin{array}{l}\text { Songan Julius K. } \\
\text { Famundi }\end{array}$ & & Siane & UPNG; Clergyman & Independent \\
\hline
\end{tabular}


Election 2007: The Shift to Limited Preferential Voting in Papua New Guinea

\begin{tabular}{|c|c|c|c|c|c|}
\hline $\begin{array}{l}\text { Ballot } \\
\text { order }\end{array}$ & Candidate & $\begin{array}{l}\text { Previously } \\
\text { contested }\end{array}$ & LLG & $\begin{array}{l}\text { Education/ } \\
\text { occupation }\end{array}$ & Party \\
\hline 19 & David Mori & 2006 & Chuave & $\begin{array}{l}\text { Secondary school } \\
\text { teacher }\end{array}$ & United Party \\
\hline 20 & George Supa & $\begin{array}{l}\text { Several } \\
\text { times }\end{array}$ & Chuave & Policeman & \\
\hline 21 & Jacob Bongi Kai & & Chuave & Unitech & Independent \\
\hline 22 & $\begin{array}{l}\text { Tony DinDongo } \\
\text { Keago }\end{array}$ & & Elimbari & & Independent \\
\hline 23 & Goerge Goi Mume & $\begin{array}{l}\text { Several } \\
\text { times }\end{array}$ & Elimbari & UPNG & $\begin{array}{l}\text { Yumi Reform } \\
\text { Parti }\end{array}$ \\
\hline 24 & $\begin{array}{l}\text { David Goro Mai } \\
\text { ex-MP }\end{array}$ & $\begin{array}{l}\text { Several } \\
\text { times }\end{array}$ & Elimbari & UPNG; lawyer & Independent \\
\hline 25 & Barex Goro Bandi & & Elimbari & UOG; educator & Independent \\
\hline 26 & James Digal Supa & 2002 & Elimbari & & Independent \\
\hline 27 & Samuel Tine & & Elimbari & $\begin{array}{l}\text { Primary school } \\
\text { teacher }\end{array}$ & Independent \\
\hline 28 & David Anggo ex-MP & $\begin{array}{l}\text { Several } \\
\text { times }\end{array}$ & Siane & Diplomat & $\begin{array}{l}\text { New Generation } \\
\text { Party }\end{array}$ \\
\hline 29 & $\begin{array}{l}\text { Huruena Copland } \\
\text { Nomane }\end{array}$ & $\begin{array}{l}\text { Once } \\
\text { before }\end{array}$ & Siane & & Independent \\
\hline 30 & Goro Stone Arigae & 2002 & Chuave & $\begin{array}{l}\text { UPNG; food } \\
\text { technologist }\end{array}$ & Independent \\
\hline 31 & Ananias Popo & & Siane & Educator & \\
\hline 32 & John Garua & & Chuave & $\begin{array}{l}\text { Secondary school } \\
\text { teacher }\end{array}$ & Independent \\
\hline 33 & Joe Amu Eremugo & & Chuave & Unitech & Star Alliance \\
\hline 34 & Francis Kaupa & & Siane & $\begin{array}{l}\text { Unitech; mine } \\
\text { engineer }\end{array}$ & $\begin{array}{l}\text { National } \\
\text { Alliance }\end{array}$ \\
\hline 35 & Simeon Gene & 2006 & Chuave & PMV owner & Independent \\
\hline 36 & $\begin{array}{l}\text { Temai Timothy } \\
\text { Komane }\end{array}$ & $\begin{array}{c}\text { Several } \\
\text { times }\end{array}$ & Elimbari & $\begin{array}{l}\text { Unitech; } \\
\text { agriculturalist }\end{array}$ & $\begin{array}{l}\text { People's } \\
\text { National } \\
\text { Congress }\end{array}$ \\
\hline 37 & Gunua Gene & 2006 & Chuave & Unitech & Independent \\
\hline 38 & Paul Gerry Gomia & & Chuave & $\begin{array}{l}\text { Secondary school } \\
\text { teacher }\end{array}$ & $\begin{array}{l}\text { People's } \\
\text { Democratic } \\
\text { Movement }\end{array}$ \\
\hline
\end{tabular}

\section{The campaign: Peaceful and more accommodative}

Compared to 2002, the campaigning under LPV in 2007 was more accommodative and peaceful, as in the 2006 by-election. Candidates were able to move freely across the electorate seeking necessary preferences from within each other's base vote areas, and voters also moved freely, a contrast with the blocking of 
candidates' territories in elections up until 2006. There was only one Chuave candidate in the 2004 Simbu by-election, and his supporters blocked other candidates and voters leaving from Chuave District.

The LPV system encourages a degree of cooperation between some candidates, if not all, and avoidance of loud confrontations. Freedom of speech and access to rival ethnic territories encouraged quieter behaviour. Candidates knew very well that primary votes were predetermined for local candidates, and made their public speeches diplomatically. At the same time, many unscrupulously facilitated large-scale campaign gifting. Vote buying and enticement in various forms was widespread, both directly and openly or capitalizing on custom. Candidates could not resist political double standards, as when they made speeches on good governance and yet participated actively in political gifting. Voters went around, sometimes with more than three candidates, accepting gifts from all and then turned around to vote their own clan's man. Voters sought and accepted campaign gifting thankfully, solemnly claiming that being Christians they would repay in votes what they gained by selling their freedom of choice.

After the by-elections and awareness, the public had some knowledge of how the LPV system would operate in the counting process. Candidates and voters knew the importance of preferences. There were several public awareness sessions on good governance which emphasized problems like corruption, and highlighted the characteristics of good leaders. The candidates publicly supported good governance and good leaders at rallies but hypocrisy was rife as some renowned candidates dished out cash openly and covertly.

Elections in Simbu are usually times of great excitement. People were accustomed to election festivities and fever, and some complained that this election was getting boring. 'Once campaign gifting is stopped then elections in the future will have no flavour', one said. Campaign gifting has become an accepted norm. The good governance awareness program pointed out that, 'Candidates who do political gifting are abusing people's freedom of choice and the process contributes to corruption'. It is probable that this awareness impacted in the distribution of preferences at the poll, and some 46 percent of those interviewed said it had changed the way they voted. However, this did not stop candidates trying to sway voters with their generosity. Campaign gifting by candidates was widespread, but the results revealed that the practice was expensive and had little or no benefit. Thus, there are signs that the LPV system may eventually reduce political gifting if the awareness continues to change the mindset of people and if candidates come to see it as a waste of resources.

The Chuave election was not entirely trouble free, however. There were a few incidents during campaigning and polling of candidates being in possession 
of illegal firearms while their supporters controlled voters. One person was reported killed in Siane during voting. After the poll there was a tribal clash as an aftermath of the election at Gogo and Wangoi in Elimbari LLG.

Some of the observers stated that supporters of two Siane candidates, Francis Kaupa (former head of the Mineral Resources Development Company, and a National Alliance candidate) and Jim Nomane (MP, Country Party), had violently attacked each other. However, before the poll at Chuave police station the two sorted out their differences. Police later arrested Francis Kaupa for being in possession of firearms without a licence. The press gave front page coverage to the incident. When I interviewed Francis Kaupa he stated that money elections are becoming part of the culture; he himself spent 'a fair bit' during the campaign.

Some supporters were seen with bush knives and axes and one was even seen with a home-made gun. Nevertheless, campaigning in the 2007 election was generally accommodative and peaceful.

\section{Campaign rallies}

There were no colourful party and nomination rallies as there were in previous elections. Only two campaign rallies were observed. The first, held in Chuave township, was organized by Meri I Kirap Sapotim, the good governance and women's advancement advocacy non-government organization. The second was held at Gogo village, organized by the people of Elimbari. Meri I Kirap Sapotim had been requested to facilitate another rally at Gogo but declined as they were doing domestic observation.

Most candidates who attended the rallies worked together for a peaceful and educated debate. The discussion focused on corruption and good governance at the two rallies. Another issue was the call to stop 'campaign houses' (see below). The candidates also stressed the importance of LPV and the use of preferences. According to the observers, a total of 1200 males, 600 females and 250 children witnessed the two rallies.

Political party campaigning had no significant effect. Political parties mattered little to the people, though party leaders such as Sir Julius Chan and Peter $\mathrm{O}^{\prime}$ Neill visited Chuave electorate. 


\section{Security}

Additional security personnel were deployed to Simbu on 16 June, weeks before the commencement of ballot paper distribution and polling.

Ballot papers and other polling necessities were escorted by polling officials and security personnel to designated areas. After the polling all the papers were returned to the police station under heavy security.

The security provided by police and soldiers was commendable. The high levels of discipline shown by Defence Force personnel contrasted with previous deployments, which were marked by immorality and brutality. Community resentment of security forces changed to acceptance and morale in the security forces was high. Cooperation between the security forces and the returning officer was good. The security force radio provided an effective means of communication. The police with field radios were in control of entire polling teams but referred matters to the returning officer.

There were a few instances where the security forces had to use force as deterrence to troublemakers, and mobile police squads defused some tense situations. Security forces contained most of the election-related violence until after the declaration of the result, but some violence erupted after the declaration, when the additional security forces had left. In one tribal clash in the aftermath of the election the West Elimbari people fought East Elimbari people, resulting in two deaths.

\section{HIV/AIDS and gender}

The many social gatherings associated with elections pose a threat of the spread of HIV/AIDS at election times. Activities are often centred on 'campaign houses', where reportedly women were sometimes used to gather support and collect votes. It is not clear whether the women were acting voluntarily. Security personnel were on their best behaviour ensuring that women were not abused by candidates or their male supporters. Campaign houses were watched to ensure that if there was any abuse of women it was kept to a minimum. Before the poll 65 percent of the 140 people interviewed said that they had attended election-related HIV/AIDS awareness sessions.

All candidates had women supporting them. Women openly spoke their minds, contributed through cooking, dancing and singing, and took control of hospitality. Five of the seven observers stated that on average 30 percent of the population that attended day-time rallies and campaigns were women and 
17 percent were young girls. They also reported that on average 38 percent of the population attending campaign houses at night were women and 24 percent young girls. In this context, it is notable that Defence Force soldiers were well behaved during the 2007 general election, compared with previous experiences.

Observers reported that women were confident that they would be able to vote freely. In 2007 women were given the long overdue chance to cast their votes separately. At most polling stations there were separate voting compartments for female and male voters. Before voting, about one-quarter of those interviewed said that they had heard about the new procedures for gender segregation during polling; after voting, 91 percent said that they appreciated the gendersegregated voting.

More women voted and more took part as polling officials than in the 2006 byelection, and there were many women counting officials. In Kerowagi at least 80 polling officials were women. Gradually, male dominance in election culture is changing.

\section{Polling}

Polling took place over two days, 11-12 July, after two days' delay because the security forces were unable to turn up on schedule. There were 69 polling teams, 27 in Siane, 21 in Elimbari and 21 in Chuave.

In the few months prior to polling the weather was dry, so accessibility was tolerable despite the dreadful road conditions. But the week before polling teams moved out was marked by downpours of heavy rain which delayed polling. Only three of the 26 hired vehicles were able to traverse the slippery roads.

At polling places, the administration of voting was often difficult to manage because of the communities' determination to corrupt the processes to help their local candidates. Polling officials and the few security personnel at each polling place were quite outnumbered and presiding officers and the police were powerless to prevent electoral malpractice. The Defence Force personnel were constantly on the move, checking potential trouble spots with small teams, and not able to deal with routine polling administration.

Nevertheless administration of the election was generally successful because of prudent forward planning by the experienced returning officer. Poor administrative support and lack of consistent funding from headquarters for polling preparation did not have much impact since in Chuave most officials and the public knew the routine and basic LPV requirements as a result of the byelection in August 2006. 
As expected, voting was peaceful, because 'community consent' was paramount at most polling places - in other words, community members had little choice but to vote as a bloc. 'Community consensus' corrupts the election as an expression of citizen's individual choice; voting may seem secret but it was 'transparent' in that everybody knew for whom each individual was voting. Voting was a community issue not a personal choice. If individuals wanted secret, personal voting they would have to answer to the community. Breaking the law for the benefit of the community was seen as heroic and mandatory. The community was driven to vote to the last registered voter on the roll, using all available ballot papers. Multiple voting was needed to keep their local candidate in the race. The principle of 'one citizen, one vote', and secret ballot were not applicable.

Chuave people, unlike their western neighbours, do not prolong ethnic clashes, perhaps because they have a different clan and tribal structure. However, they have strong clans and are a deeply divided society. This is shown in the common expressions: ' $\mathrm{G}$ for $\mathrm{G}$ ' or ' $\mathrm{K}$ for $\mathrm{K}$ ' (meaning 'Gomia for Gomia' and 'Kamare for Kamare'). Clan and tribal affiliation results in community consensus which is manifested in controlled bloc voting. The poll results confirmed the practice of bloc votes, in that local candidates scored more than 90 percent of first preferences in ballot boxes used at single polling places. 'Outside' tribal or clan candidates who had strong connections shared the other preferences in the box. Under LPV the election is accommodative to a limited extent; however, voter intimidation and bloc voting were still prevalent in 2007.

The roll was not used to identify voters. At all polling stations, the voters formed two lines - one for man and one for meri-or a single line with both sexes queuing up to vote. Names were called in some places but mostly just 'Next!' or 'Meri!' or 'Man!'. The indelible ink intended to prevent cheating was of no use because it can be erased. ${ }^{2}$

Among 120 voters interviewed after the poll, 97.5 percent had voted, and more than 60 percent said that they had known how to vote properly. However, 42 percent said that they had found the new voting system confusing and a third said that they had required assistance in voting. Twenty-one percent reported that they had experienced intimidation while voting. However, the great majority (93 percent) felt that the 2007 election was much better than 2002 election conducted under FPTP voting.

According to the observers at six polling places, on average 9 percent of those who voted were clearly under the legal voting age of 18 . Of the 14 percent who said they had filled in an enrolment claim, 97 percent had voted. Some

2 The efficacy of indelible ink is also discussed in chapter 27. 
40 percent thought their names were on the roll. This information does not correlate, but many people registered the names of others, including under-aged people, and multiple voters voted on behalf of others. Of those interviewed after voting, 33 percent admitted that they voted more than once. The extent of electoral fraud suggests that citizens did not have a fair and equal vote, and often not a free vote.

The 2007 election introduced a new ballot paper, which was different from that used in the 2004 and 2007 LPV by-elections. Candidates' pictures and party details were listed on posters, and each candidate was allocated a number. Using these posters, voters had to write the numbers or names of three candidates onto the ballot paper in order to vote formally, and do the same for both Open and Provincial seats. However, candidate posters were issued very late and were very small and confusing to most of the voters. It took about three to six minutes for old and illiterate voters to vote. This helped justify the existing practice in Chuave (and the Highlands generally) of local men 'assisting' voters who needed help, when there were insufficient polling officials to perform this task. These people, often the agents of candidates, then also checked each ballot paper for formality before it was deposited in the ballot box. Incorrectly marked ballot papers were deemed informal and removed from the count. In 2007, the informal vote was 0.7 percent of the total vote, up from the 0.4 percent informal vote in 2006. This is a very low informal vote, and can only be explained by the high number of assisted voters, who happened to ensure that the community consensus was followed.

The public seemed to regard these flaws in electoral administration as acceptable, because 93 percent of the respondents said that the 2007 election was a good outcome and better than previous elections.

\section{Counting}

The scrutiny of votes took place at Dixon's Oval, Kundiawa, about 30 kilometres west of Chuave. The counting centre was open and accessible to everybody. The scrutineers stood outside the makeshift shelter during the counting period and had a good view of the whole process. The candidates were allocated seats outside the counting fence, enabling them to watch but not take part.

There was good liaison between the many parties involved during the counting the provincial election manager, returning officers, counting officials, security forces, observers, candidates, scrutineers and the PNGEC headquarters in Port Moresby. Most of the parties communicated verbally; some used mobile phones. 
The observers noted that the security forces were very strict. There were four checkpoints with fully armed personnel doing thorough checks of bags, folders wallets, shoes and the entire person to prevent any counting fraud with extra ballot papers or bribery of counting staff. Any suspected person, including counting officials arriving late, were punished on the spot and forced to do push-ups or sit-ups, or were kicked or belted, and most of the security personnel swore at the offenders. There were no serious offenders, as in previous elections, that warranted charges.

Some of the observers reported that most of the counting officials were not fully trained and had little prior knowledge of LPV counting processes. Most of the scrutineers were ill prepared and did not fully understand the LPV counting process. This led to some confusion and delay in the early stages of the count. Nevertheless, despite some re-counts during the primary count to make sure figures were accurate, the counting process went well.

About half the counting officials in the Simbu provincial counting centre were women, following a pattern established in 2004 . Women seem to be regarded as less likely than men to commit fraud in elections.

\section{Results}

The count by the Chuave team was more efficient than that in other open electorates and was the first completed. This was due to the selection of some senior experienced officers and the use of excellent management practices at the counting centre. Rotating of counting officials and appointment of supervisors for each shift helped make the counting efficient. Having an open and transparent process by double checking and allowing scrutineers to understand and witness every step reduced suspicion, and collaboration speeded up what was a complex process.

The winner in Chuave was declared on the 25 July. The sitting MP, Jim J. Nomane from Siane, was declared with 56 percent of votes in the final count. The runner-up, Temai Timothy Komane from Kureri village, Elimbari, collected 44 percent. Looking at the mandate as a proportion of total allowable votes, however, the winner scored only 31.6 percent of total votes while the runnerup scored 24.8 percent; exhausted ballot papers - those eliminated from the count - totalled 12,867, 43.6 percent of the 30,611 allowable ballot papers.

Nomane led on first preferences with 4931 votes (16.1 percent of allowable votes), while the runner-up scored 3296 first preferences. The winner collected 4740 preferences (49.0 percent of his final tally) and so won with a wide spread of support, as he had in 2006. The runner-up, Komane, scored 3296 primary 
votes and gained 4301 second and third preferences, which was fewer than the winner but 56.6 percent of his final tally. (See Table 17.3 in the appendix at the end of this chapter.)

Compared to the 2006 by-election, the 2007 election showed a reduction in the proportion of ballot papers exhausted during the eliminations, which suggests that voters directed their preferences towards stronger candidates, and that fewer preferences were 'wasted' on minor candidates. In 2006 some 20,381 of 32,691 votes (62 percent) were exhausted; that meant the 'absolute majority' was reached from only 39 percent of the allowable ballot papers. In 2007 the corresponding figure was 56.4 percent.

With two previous experiences of LPV, the Chuave voters had clearly learnt how to use their votes more effectively. In 2007, with 29 candidates, five more candidates than in 2006, Nomane received a higher primary vote (16.1 percent of the allowable first preference votes) than in 2006 (13 percent).

A more dramatic change is shown by comparison with 2002, when there were 37 candidates, nine more than 2007. In 2002 the winner, David Anggo, received 4495 votes and his mandate under FPTP was 9 percent of the 49,909 votes counted. In $2002 \mathrm{Jim}$ Nomane was the runner-up receiving 4403 votes (8 percent). His mandate thus increased considerably in 2006 and 2007.

There is always a problem determining causation, and LPV was not the only factor which had changed Chuave politics by 2007, another being that 37 percent fewer votes were allowed in the count. Nomane and Anggo both come from the Siane LLG, where the local political balance had changed. Nomane, the younger man, had created a stronger base than Anggo, as analysed in our 2006 report (Standish and Kaupa 2006). In 2007 Nomane doubled his primary vote while Anggo lost more than half his vote, dropping to 2075 (7 percent). Nomane's increased final tally in 2007 derived mainly from the receipt of 53 percent of preferences active in the final count. Given these major changes, Nomane's 32 percent mandate in 2007 is not directly comparable to Anggo's 9 percent mandate in 2002 .

\section{An overview of outcomes}

The 2007 election was an improvement on previous Chuave elections. The security forces sought public cooperation, rather than intimidating people. Their behaviour was professional and disciplined compared to behaviour observed previously. The heightened security probably deterred overt intimidation and the open use of firearms at polling booths, but the limited size of security forces in the communities meant that they had little effect on the actual polling, 
because they were outnumbered by highly motivated people determined to cheat to help their candidates. Voters managed their own polling places in their own way. Electoral officials empowered to manage polling were powerless at the polling sites. Political parties were regarded as insignificant by voters. How, then, was the 2007 election in Chuave more peaceful, accommodative and better than the 2002 election?

Rather than challenging each other aggressively, as in previous elections, the candidates debated publicly, addressing neutral common issues such as corruption and the need to promote good governance, though they displayed double standards when they sought to exploit the customary ethic of reciprocity ('give and take') by practising modern political gifting. Campaigning for the LPV election was expected to be more accommodative than under FPTP, and it was-although it seemed that the price of access was more widespread generosity by candidates in order to get a hearing and obtain pledges of primary votes or preferences. The LPV system allowed village people to accommodate their wantok and friends in distributing preferences while voting. Yet strong affiliations for local candidates predetermined the distribution of preferences. Paradoxically, voter intimidation, multiple voting and under-age voting enabled polling within local communities to be peaceful, with voters required to follow their community's consensus.

Compared with 2002, there were fewer campaign houses and feasting was less evident. No loud party rallies were held, and candidates attended only two public rallies on designated neutral locations to debate good governance and corruption issues. The winning candidate received a stronger mandate than in the 2006 by-election. Campaign gifting had worked in the 2006 by-election but not in 2007. Local communities overrode important election procedures. Nonetheless more women were seen voting freely and participating in the electoral process.

All these good indicators failed to override the element of bloc voting. From observing the count, it was clear that primary votes and preferences were shared according to local affiliations, and local candidates scored more than 90 percent in many polling places. The results from individual boxes from the 69 polling locations showed that results were still influenced by community consensus, with widespread bloc voting; preferences are controlled by local candidates and their supporters. In this sense, for voters in their villages, the LPV election was seen as much the same as the FPTP system.

The LPV system provides scope for a greatly increased mandate, but in Chuave in 2007 the elected member still received less than half the votes in the electorate. The bulk of each candidate's votes and preferences came from specific 
sections of the electorate; as in previous elections, community consensus was overwhelming. The change from FPTP to LPV has not, to date, helped create 'people's rule'.

The first full use of the Organic Law on the Integrity of Political Parties and Candidates seems to have had little or no influence at the community level, in terms of mobilizing people to vote for political parties. In Chuave the outcome of the election was much the same as in the previous elections, in that local factors were of primary importance.

In the Highlands it will probably take a while before the people participate in a truly national election.

\section{References}

Standish, B. and Kaupa, W. S. G., 2006. 'Chuave Open Electorate By-Election August 2006: Report of Independent Observers', 19 November 2006.

Warry, W., 1987. Chuave Politics: Changing Patterns of Leadership in the Papua New Guinea Highlands. Political and Social Change Monograph No. 4. Canberra: Department of Political and Social Change, Research School of Pacific Studies, The Australian National University.

\section{Appendix}

\section{Table 17.2: Voting statistics for Chuave Open electorate, 2007 election}

\begin{tabular}{lrl}
\hline Number of registered voters & 31,034 \\
Total votes cast & 30,838 & \\
Informal votes & 227 & (0.7\% of total ballots cast) \\
Total allowable ballot papers & 30,611 & \\
Total ballot papers remaining in count & 17,268 \\
Total votes distributed & 22,384 \\
Exhausted ballot papers & $13,343 \quad$ (43.6\% of total allowable papers) \\
Absolute majority $(50 \%+1)$ & 8,635 \\
\hline
\end{tabular}


Election 2007: The Shift to Limited Preferential Voting in Papua New Guinea

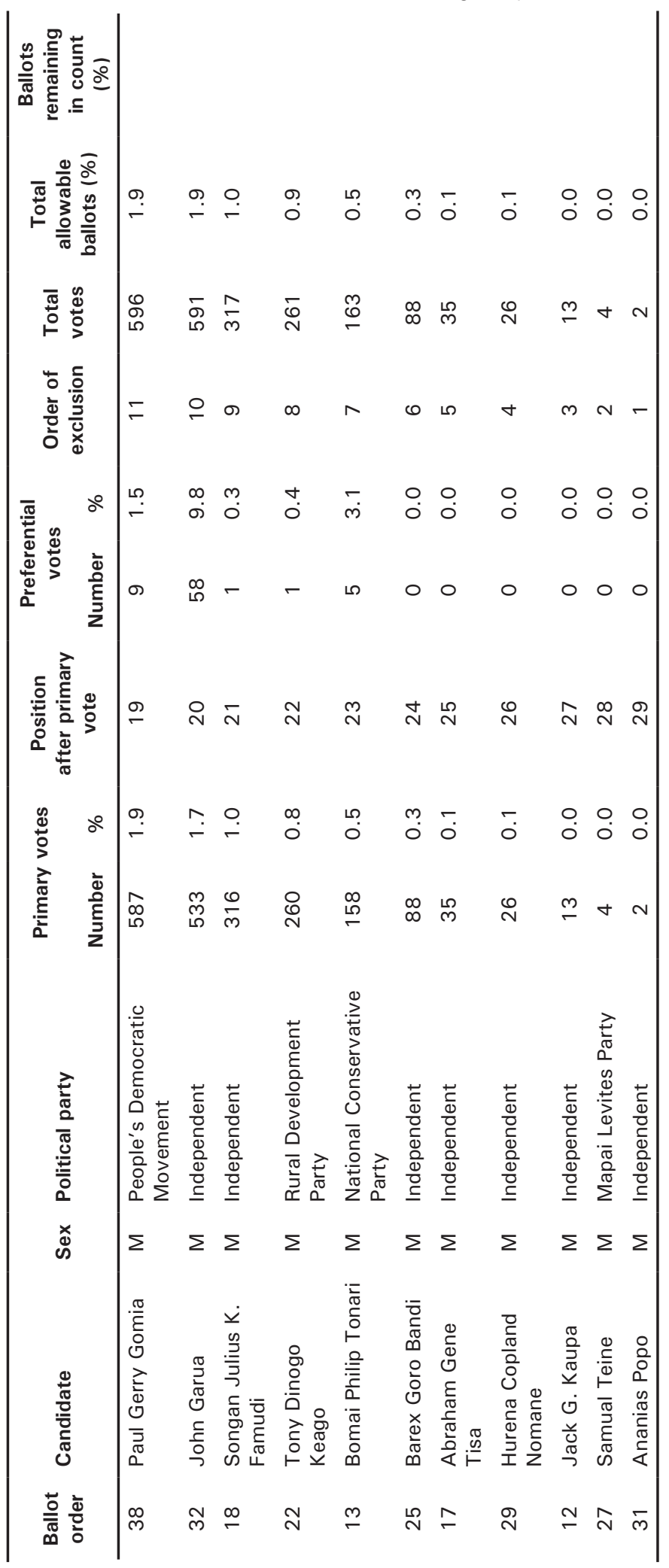

